\title{
Algoritmul - participant în procesul de încheiere a contractului
}

\section{The Algorithm - Participant at the Conclusion of Contract}

\author{
Crina-Maria Stanciu ${ }^{1}$, Codrin-Alexandru Ştefăniu ${ }^{2}$
}

Rezumat: La momentul în care se doreşte încheierea unui contract, subiectul de drept se găseşte în ipostaza de a alege un scenariu potrivit acestei etape (fie negociază clauzele contractului, fie are loc un schimb al ofertei şi al acceptării). $\mathrm{Cu}$ toate acestea, insul urmăreşte adaptarea acestui proces la cerinţele din prezent pe care, de asemenea, omul şi nevoile schimbătoare le vor dicta (încheierea contractului într-un termen scurt; interpretarea corectă a clauzelor contractuale în vederea respectării voinţei reale a părţilor). În acest sens, lucrarea va încerca să releve nivelul de încredere pe care omul îl va putea avea în algoritm, pornind de la modul în care este acesta tratat din punct de vedere juridic, comparându-se condiţiile necesare a fi îndeplinite la încheierea unui contract cu modul în care este programat acest nou instrument.

Cuvinte-cheie: algoritm; contract; ofertă; acceptare; eroare

\begin{abstract}
At the moment when it is desired to conclude a contract, the subjects of law find themselves in the situation of choosing a scenario in accordance with this stage (either they negotiate the clauses of the contract or there is an exchange of offer and acceptance). However, the individual seeks to adapt this process to the current requirements that mankind and changing needs will also dictate (concluding the contract in a short time; correct interpretation of the contractual clauses in order to respect the real will of the parties). In this sense, the paper will try to reveal the level of trust that humans can have in the algorithm, starting from the way it is treated from a legal point of view, all the way to comparing the necessary conditions to be met when concluding a contract with how this new tool is program.
\end{abstract}

Keywords: algorithm; contract; offer; acceptance; error

\section{Introducere}

Lumea care ne înconjoară este una a schimbărilor generate de nevoile omului şi, ulterior, ale societăţii care îl cuprinde. Această „nevoie”, a cărui sens s-a lărgit din ce în ce mai mult, a determinat şi apariţia obligaţiei insului - mai întâi faţă de familie, ulterior faţă de persoanele din jur şi cu care intră în contact. Cu alte cuvinte,

${ }^{1}$ Doctorand, Facultatea de Drept, Universitatea „Alexandru Ioan Cuza” din Iași, e-mail: crinas17@yahoo.com.

${ }^{2}$ Teaching Assistant, University of Aberdeen Scotland, e-mail: codrinstefaniu36@gmail.com. 
obligaţia a ajuns să lege omul de lucrurile din jurul său din ce în ce mai mult ${ }^{3}$. Astfel, insul sau subiectul de drept este legat prin uniune, percepută ca pe o formă a rudeniei - realizată prin intermediul căsătoriei ${ }^{4}$. De asemenea, se creează o convenţie prin intermediul legăturii de sânge care denotă încă o dată obligaţia pe care o avem unii faţă de ceilalţi în cadrul familiei. Familia poate fi, astfel, percepută drept izvorul unui prim contract pe care îl încheiem pe timpul vieţii.

Extrapolând sensul obligaţiei la nivelul societăţii, observăm creşterea numărului de înţelegeri care sunt realizate între oameni pentru urmărirea şi ducerea la bun final ale unor deziderate fie ele subiective sau obiective. Acestea din urmă sunt conduse spre punctul final prin intermediul unui schimb constant şi, respectiv, cu ajutorul mai multor îndatoriri pe care omul şi le asumă şi care se completează una pe cealaltă: a da, a primi şi a restitui ${ }^{5}$. La momentul în care încercăm să conturăm un raport obligaţional cu ajutorul acestora trei, ne gândim, înainte de toate, la formarea acestuia: la ofertă şi acceptare sau la parcursul negocierii. Ne punem întrebări precum aceea dacă putem sau nu constitui acel raport, ce formă va lua voinţa noastră în plan concret, dacă motivul realizării raportului obligaţional se încadrează în limitele prescrise de lege, respectiv, ce anume urmărim prin acel act. Toate aceste elemente vor fi discutate cu partea alături de care stabilim raportul obligaţional. Acest proces nu ar putea deveni, însă, mai simplu?

Omul a ajuns să evolueze din ce în ce mai mult: nevoile sale s-au schimbat, cerinţele s-au diversificat. A ajuns, în acest fel, la un impas: doreşte rezultatul finit al unei înţelegeri sau contract cât mai repede, iar acesta să se plieze voinţei şi solicitării sale. De aceea s-a creat un nou participant în procesul de formare al contractului părţilor, în ipostaza unui algoritm care să preia voinţa insului exprimată în plan abstract şi să o aducă în planul concret, gata de a fi implementată. Acestea, presupun, însă respectarea cuvântului dat, precum şi un schimb de consimţăminte, schimb pe care încercăm a-l realiza împreună cu un nou participant sau, chiar, o nouă formă de exprimare a consimţământului în plan juridic algoritmul. Insul ajunge, astfel, să îşi exprime voinţa, dar mediat de un set de reguli care se pot schimba în funcţie de cerinţele imediate ale persoanei. Se realizează o convenţie a părţilor printr-un acord de voinţă care s-a dezvoltat pe baza a ceea ce a fost analizat şi interpretat prin cifre şi cuvinte.

\section{Personalitatea juridică a algoritmului şi rolul acesteia în conceperea unui contract}

Algoritmul reprezintă un proces ce conţine instrucţiuni, prin intermediul cărora un set de date de intrare se transformă într-un set de date de ieşire. Instrucţiunile au la bază calcule matematice ale căror caracteristici trebuie sa fie

\footnotetext{
${ }^{3}$ Gaius, Instituțiunile, trad. Aurel N. Popescu, Editura Academiei Republicii Socialiste România, București, 1982, p. 218.

${ }^{4}$ A. Supiot, Homo juridicus: eseu despre funcția antropologică a dreptului, Editura Rosetti Educational, București, 2011, pp. 150-151.

${ }^{5}$ Idem, p. 152.
} 
suportate de un calculator. Datele de intrare şi cele de ieşire pot fi interpretate ca fiind modul de comunicare al unui algoritm cu lumea exterioară. Acesta transformă un şir de cifre binare într-un text care poate fi citit de către oameni. Numele „algoritm” a fost derivat din numele matematicianului Mohammed al-Khowârizmî care in secolul al IX-lea a creat regulile pentru adunări, scăderi, înmulţiri şi împărţiri ale numerelor raţionale ${ }^{6}$. Numele acestuia, a fost tradus iniţial în latină sub forma „Algorismus”, din care a derivat versiunea actuală a cuvântului „algoritm”. Primul algoritm a fost inventat de către matematicianul grec Euclid, în jurul anului 300 î. $\mathrm{Hr}^{8}$. Acest algoritm are funcţionalitatea de a găsi cel mai mare divizor comun a două numere? .

În continuare ne dorim să prefigurăm modul în care algoritmul ar pute fi inclus în sfera juridică. $\mathrm{Cu}$ alte cuvinte, vom încerca să integrăm algoritmul în rândul subiectelor de drept capabile a se obliga şi a-şi exercita drepturile. Astfel, prin interpretarea art. 2 alin. (1) C. civ. Dispoziţiile prezentului cod reglementează raporturile patrimoniale şi nepatrimoniale dintre persoane, ca subiecte de drept civil. coroborat cu art. 25 alin. (2) şi (3) C. civ. Persoana fizică este omul, privit individual, ca titular de drepturi şi de obligaţii civile. Persoana juridică este orice formă de organizare care, întrunind condițiile cerute de lege, este titulară de drepturi şi de obligaţii civile. ni se arată că, pentru a fi considerat subiect de drept în sensul legii civile, este necesară calitatea de om, de persoană care evoluează odată cu societatea în care trăieşte, ori calitatea de subiect colectiv, care îndeplineşte condiţiile cerute de lege. Prin urmare, definitoriu pentru sfera legală a unei societăţi este modul în care a ales legislaţia să trateze noţiunea de „persoană”, aşa cum o arăta şi filozoful Gustav Radbruch ${ }^{10}$. În dreptul roman, lexemul „persoană” sau persona era utilizat pentru a ilustra diferitele roluri pe care le avea omul în variatele momente ale vieţii sale. Astfel, acesta putea deţine o varietate de personae - pater familias, angajator, membru de familie, vânzător, testator ${ }^{11}$. Aceste roluri creau imaginea statutului pe care omul îl ocupa în societatea romană - fie prin analiza lui status libertatis (oameni liberi şi sclavi), status civitatis (diferenţia cetăţenii de străini) şi status familiae (paterfamilias sau filiusfamilias). Ceea ce poate fi remarcat este inexistenţa legăturii dintre persona şi omul în sens biologic - persona aducea cu sine statutul, rolul legal, capacitatea legală, iar omul în sens biologic aducea doar carcasa care urma a fi umplută sau nu de viaţă juridică.

${ }^{6}$ H. Gabriel, Secretele Algoritmului, p. 2, [Online] la https://sites.google.com/site/ secretelealgoritmului/ce-este-un-algoritm, accesat 12.10.2021.

${ }^{7}$ Ibidem.

${ }^{8}$ Idem, p. 3

${ }^{9}$ Ibidem.

${ }^{10}$ B. van Beers, The Changing Nature of Law's Natural Person: The Impact of Emerging Technologies on the Legal Concept of the Person, în German Law fournal, Vol. 18, No. 03, p. 560, [Online] la https://www.researchgate.net/publication/331613123_The_Changing Nature_of_Law's_Natural_Person_The_Impact_of_Emerging_Technologies_on_the_Legal _Concept_of_the_Person, accesat 12.09.2021.

${ }^{11}$ Idem, p. 572. 
În continuare, vom încerca să aflăm dacă persona sau conţinutul juridic al subiectului de drept nu ar putea fi conferit şi unui algoritm, la momentul în care acesta este inclus în cadrul procesului de formare al unui contract. Astfel, trebuie, în primul rând avut în vedere faptul că acordarea personalităţii juridice unei noi entităţi presupune crearea unei ficţiuni juridice capabile să se adapteze cerinţelor prezentului. Algoritmul reprezintă nevoia de adaptare a societăţii la planul economic, juridic, social care s-a creat prin evoluţia tehnologică ${ }^{12}$. Urmare a acestui fapt, vom încerca prefigurarea unei forme juridice care să explice şi să constituie un cadru legislativ potrivit utilizării algoritmului în materie precontractuală. Am putea încadra, în primul rând, algoritmul în sfera persoanelor fizice?

Pentru a realiza acestea ar trebui ca algoritmul să facă parte din specia umană; personalitatea acestuia să îşi găsească începutul în naştere, iar moartea să reprezinte punctul final al demersului nostru ${ }^{13}$. Algoritmul, spre deosebire de om, nu se naşte sau moare, ci este construit şi ar putea, cândva, să prezinte erori de funcţionare ${ }^{14}$. De asemenea, algoritmul nu presupune o organizare de sine stătătoare şi un patrimoniu aparte, spre a putea fi considerat o persoană juridică. $\mathrm{Cu}$ toate acestea, prezintă un scop bine determinat prin prisma regulilor pentru care este construit. Astfel, putem observa un transfer incipient de cunoştinţe aferente omului, privit individual, către algoritm, privit ca pe un intermediar pentru ceea ce doreşte a realiza insul. Omul se schimbă, iar această schimbare determină modificarea mediului legislativ prin crearea unui nou participant în materie contractuală, pe care îl vom numi în continuare agent al voinţei insului sau intermediar între voinţa unei persoane şi voinţa altei persoane.

Algoritmul, agentul sau intermediarul dintre voinţa unei persoane şi a alteia, ar putea fi analizat şi conceput fie ca pe o persoană juridică cu drepturi recunoscute de lege, fie drept un spaţiu care să adăpostească capacitatea persoanei şi care să dobândească, în acest fel, drepturi, fie ca pe un spaţiu care acumulează o aptitudine sau capacitate în vederea creării unor relaţii legale ${ }^{15}$. Care ar fi soluţia cea mai potrivită?

\section{Formarea contractului şi rolul acordat algoritmului în cadrul acestui proces}

Care este fundamentul în virtutea căruia sunt negociate şi acceptate variatele oferte ale cocontractanţilor prin intermediul inteligenţei artificiale? $\mathrm{Cu}$ alte cuvinte, inteligenţa artificială va acţiona în acest demers drept un reprezentant

${ }^{12}$ R.F. Reier Forradellas, Digital Transformation and Artificial Intelligence Applied to Business: Legal Regulations, Economic Impact and Perspective, în Laws, 2021, pp. 1-3, [Online] la https://www.mdpi.com/2075-471X/10/3/70/html, accesat 10.10.2021.

${ }^{13}$ B. van Beers, op. cit., p. 563.

${ }^{14}$ M.D. Bob, Manual elementar de drept privat roman, Editura Universul Juridic, București, 2019, p. 87.

${ }^{15}$ J.C. Gellers, Rights for Robots. Artificial Intelligence, Animal and Environmental Law, Editura Routledge, New York, 2021. 
legal al uneia dintre părţi faţă de cealaltă sau aceasta nu poate fi percepută decât ca pe un simplu instrument al cocontractantului ${ }^{16}$ ? În ambele ipoteze prezentate se remarcă un principal factor de risc în realizarea contractului, respectiv, dacă algoritmul, la momentul în care va negocia clauzele actului pentru partea care îl utilizează, exprimă sau nu un consimţământ valabil. Astfel, în continuare vor fi ilustrate două modalităţi de organizare a procesului de încheiere a contractului, pornindu-se de la scenariul care trebuie urmat, ca regulă, în această materie.

În primul rând, pentru încheierea unui contract va fi necesară exteriorizarea consimţământului părţilor în sensul intenţiei de a fi legate de termenii şi de condiţiile asupra cărora acestea au convenit. In acest fel, ne sunt devoalate şi condiţiile de validitate care trebuie, de asemenea, îndeplinite de contractanţi pentru ca actul respectiv să îşi producă efectele sub auspiciile libertăţii de voinţă a părţilor: capacitate, consimţământ, obiect şi cauză a actului juridic ${ }^{17}$.

În ceea ce priveşte condiţia capacităţii, respectiv - a aptitudinii părţilor de a fi titulare de drepturi şi de obligaţii aduse împreună cu ajutorul contractului - vom încerca a prefigura un transfer de capacitate dinspre persoana interesată spre algoritm, astfel încât acesta să poată încheia acel act, deoarece partea pentru care a intervenit are capacitatea necesară ${ }^{18}$. Acestea se vor petrece la momentul la care utilizăm un algoritm pentru negocierea clauzelor unui contract.

Obiectul şi cauza contractului trebuie să existe, să fie bine determinate, posibile şi să fie în acord cu legea şi cu morala. Cele două condiţii de validitate ale contractului menţionate anterior vor putea fi identificate prin intermediul termenilor şi condiţiilor actului, astfel încât să reflecte ceea ce au urmărit părţile a realiza în plan juridic. În ceea ce priveşte algoritmul în contracte, condiţiile vor putea fi determinate prin raportare la setul de date, de reguli care i-au fost atribuite algoritmului, date care reflectă, de fapt, voinţa finală a părţilor.

În ceea ce priveşte consimţământul părţilor, respectiv manifestarea de voinţă în sensul încheierii unui contract, vom avea în vedere, pe de o parte, parcursul intern de formare a consimţământului, acesta din urmă trebuind a fi serios, liber şi exprimat în cunoştinţă de cauză, punându-se un mare accent pe existenţa sau pe inexistenţa viciilor de consimţământ ${ }^{19}$. În cadrul parcursului extern care ilustrează în realitate, în planul concret, voinţa părţilor, consimţământul poate fi conturat fie prin negocierea contractului, fie prin aducerea laolaltă a ofertei şi a acceptării ${ }^{20}$.

${ }^{16} \mathrm{M}$. Oliver, Contracting by artificial intelligence: open offers, unilateral mistakes, and why algorithms are not agents, în Australian National University fournal of Law and Technology, 2021, p. 47, [Online] la https://anujolt.org/article/24466-contracting-byartificial-intelligence-open-offers-unilateral-mistakes-and-why-algorithms-are-notagents, accesat 18.10.2021.

${ }^{17}$ C.T. Ungureanu, Drept civil. Partea generală. Persoanele, Editura Hamangiu, București, 2013, p. 127.

18 Idem, p. 128.

${ }^{19}$ Idem, pp. 127-128.

${ }^{20}$ L. Pop, I.-F. Popa, S.I. Vidu, Curs de drept civil. Obligațiile, Editura Universul Juridic, București, 2015, p. 53. 
Consimţământul este o condiţie aparte şi care nu poate fi uşor îndeplinită prin intermediul algoritmului. Această exteriorizare a consimţămânului presupune scoaterea la liman a intenţiei, a voinţei de a contracta a părţilor. Pe de o parte, ne gândim la realizarea negocierilor prin încheierea unor acte care să poată ilustra mai bine această voinţă; dar, din nou, ne punem întrebarea cum ar putea algoritmul să exprime voinţa părţii pentru care intervine la nivelul unei scrisori de intenţie, unui pact de opţiune sau a unei promisiuni de a contracta. Mai mult decât atât, cum va putea realiza algoritmul acestea în cadrul mecanismului de formare a contractului prin constituirea unei oferte şi acceptarea acesteia. Observăm, de asemenea, necesitatea îndeplinirii condiţiilor de validitate anterior menţionate inclusiv în ceea ce priveşte aceste acte (oferta fiind un act juridic unilateral prin care se propune unei alte părţi încheierea unui contract în anumite condiţii, conform art. 1.188 alin. (1) C. civ., iar acceptarea fiind actul prin intermediul căruia voinţa este redată în sensul achiesării la încheierea contractului în anumite condiţii $\left.{ }^{21}\right)$.

În sistemul de drept anglo-american, este schimbată definiţia contractului, acesta reprezentând o sumă de promisiuni care vor conduce la încheierea şi executarea acestuia ${ }^{22}$. Astfel, aducem împreună mai multe promisiuni care vor crea sfera de aplicare a contractului. De asemenea, promisiunea presupune aducerea în prim-plan a elementelor circumscrise voinţei, precum şi intenţia subiectului de drept de a respecta cele la care s-a obligat ${ }^{23}$. Astfel, oferta şi acceptarea vor putea fi înţelese drept promisiuni legate printr-o condiţie - promisiunea de a face, a nu face sau a da ceva, în schimbul promiterii contraprestaţiei de către cealaltă parte ${ }^{24}$. Se vorbeşte, în acest fel, despre existenţa unei condiţii suspensive - cealaltă parte trebuie, de asemenea, să realizeze o promisiune, pentru a putea fi creat actul juridic în cauză. Mai mult decât atât, prin acest schimb de promisiuni se ajunge la îndeplinirea lui consideration ${ }^{25}$ (sau beneficiul urmărit prin încheierea contractului), asemuit cauzei sistemului de drept din România. Aceste promisiuni, de asemenea, vor prezenta manifestarea de voinţă a unei persoane, iar algoritmul va avea sau nu un rol important în acest demers, chiar de participant indirect. Ceea ce importă este voinţa ofertantului (intenţia ca oferta să fie acceptată de cealaltă

${ }^{21}$ Idem, p. 80.

${ }^{22}$ Restatement Second of Contracts $\S 1$. "A contract is a promise or a set of promises for the breach of which the law gives a remedy, or the performance of which the law in some way recognizes as a duty".

${ }^{23}$ La nivelul Europei, se remarcă un interes crescut pentru modul în care se formează contractul și, mai cu seamă, în articolul 2:101 din cadrul The Principles of European Contract Law: "A contract is concluded if: the parties intent to be legally bound, and they reach a sufficient agreement without any further requirement".

${ }^{24}$ M. Hogg, Promises and Contract Law. Comparative Perspectives, Editura Cambridge University Press, The Edinburgh Building, Cambridge, 2011, p. 210.

${ }^{25}$ E.W. Weitzenböck, English Law of Contract: Consideration, în Norwegian Research Center for Computers \& Law, 2012, p. 2, [Online] la https://www.uio.no/studier/emner/ jus/jus/JUS5260/v12/undervisningsmateriale/Consideration.pdf, accesat 18.10.2021. 
parte), dar şi caracterul cert, respectiv; comunicarea ofertei către posibilul cocontractant ${ }^{26}$.

Pentru a putea înţelege mai bine rolul algoritmului în cadrul procesului de formare a contractului, au fost create două teorii care au aplicabilitate atât la nivelul negocierilor, cât şi la nivelul mecanismului de ofertă şi acceptare ${ }^{27}$. Aceste teorii gravitează în jurul sistemului de drept anglo-american, dar; după cum se va putea observa, acestea vor putea să îşi găsească aplicarea şi în sfera dreptului român.

În primul rând, s-a argumentat în sensul utilizării algoritmului drept reprezentant al părţii pentru care intervine şi negociază sau acceptă ori realizează o ofertă ${ }^{28}$. Teoria reprezentării juridice aduce cu sine, astfel, posibilitatea de negociere şi de încheiere a contractului prin transferarea unei părţi a autorităţii subiectului de drept către algoritm, respectiv; voinţa persoanei se va putea realiza prin intermediul acestuia. Condiţia de validitate a consimţământului va fi, prin urmare, respectată. Se consideră, însă, că interesul părţii este alterat de intervenţia algoritmului, deoarece acesta va constitui oferta cu ajutorul unui input general. De asemenea, reprezentantulva fi unul artificial deoarece acesta nu este o persoană, „om, privit individual” 29 . S-a creat, astfel, o ficţiune juridică pentru a acoperi o lacună în domeniu. Totodată, legea va trebui să se reorienteze şi să considere intenţia şi cunoştinţele incluse în algoritm la fel cum ar trata raportul dintre reprezentat şi reprezentant (cunoştinţele reprezentantului sunt ale reprezentatului). În plus, algoritmul nu va mai trebui inclus în sfera subiectelor de drept, a persoanelor, putând să îşi realizeze scopul fără a mai fi necesară acordarea unor drepturi şi obligaţii distincte. Mai mult decât atât, Uniform Electronic Transactions Act (1999) prezintă o formulare din care putem deduce susţinerea acestei teze prin faptul că încearcă facilitarea încheierii de contracte prin intermediul algoritmilor, cu ajutorul unor dosare electronice sau evidenţe electronice şi a semnăturii electronice (se creează o egalitate între dosarul fizic, semnătura olografă şi

${ }^{26}$ G. Quinot, Offer, Acceptance, and the Moment of Contract Formation, in loc. cit., Hector MacQueen, Reinhard Zimmermann, European Contract Law. Scots and South African Perspectives, Editura Edinburgh University Press, Edinburgh, 2006, pp. 76-78.

${ }^{27}$ Aceste teorii au trebuit a fi formulate și datorită lacunelor legislative în materie de contracte, precum și al modului în care percep teoreticienii și practicienii dreptului schimbarea tehnologică care planează în această sferă (algoritmul va realiza sarcini complexe; algoritmul va putea fi perceput fie ca pe o mașinărie, fie ca pe un agent/reprezentant al părții; noile reguli care vor fi impuse în ceea ce privește reponsabilitatea algoritmului în cazul în care nu se respectă cele prezentate în momentul negocierii și al stabilirii clauzelor contractuale). U. Pagallo, The Laws of Robots: Crimes, Contracts, Torts, Editura Springer Science+Business Media Dordrecht, Dordrecht Heidelberg New York London, 2013, p. 94.

${ }^{28}$ L.H. Scholz, Algorithmic Contracts, în Stan. Tech. L. Rev., nr. 128, Stanford, California, 2017, p. 164, [Online] la https://law.stanford.edu/publications/algorithmic-contracts/, accesat 1.10.2021.

${ }^{29}$ S. Chopra, L.F. White, Artificial Agents and the Contracting Problem: A Solution Via an Agency Analysis, în University of Illinois Journal of Law Technology \& Policy, 2010, pp. 363365, [Online] la https://ssrn.com/abstract=1589564, accesat 15.10.2021. 
instrumentele electronice $)^{30}$. Algoritmul va putea, prin urmare, să semneze contractul, iar rezultatul negocierilor va putea fi inclus într-un registru electronic (putându-se proba cele realizate de algoritm). Raportul dintre reprezentat şi reprezentant se va contura fie prin convenţie, fie prin ratificare, cea de pe urmă metodă fiind aceea care să fie utilizată pentru a lega partea de cel care va acţiona în interesul ei. Ratificarea va fi folosită deoarece societăţile/persoanele juridice şi persoanele nu vor putea să prevadă fiecare acţiune a algoritmului, dar prin ratificare procedeul se simplifică. Se pot crea modalităţi de evaluare a algoritmului în actele pe care le încheie, iar reprezentantul va avea, în acest fel, control asupra activităţii algoritmului ${ }^{31}$. Cu alte cuvinte, la momentul în care algoritmul va încheia un contract, cel reprezentat va avea posibilitatea de a-l analiza, iar în cazul în care actul respectiv nu ar fi considerat a fi încheiat în interesul său, persoana va avea posibilitatea de a refuza ratificarea acelui act. $\mathrm{Cu}$ toate acestea, va exista un risc pe care reprezentatul să şi-l asume pentru cazul în care algoritmul nu va funcţiona corespunzător sau nu va executa contractul format în conformitate cu cerinţele negociate.

O a doua teorie care încearcă a o înlocui pe cea precedentă a fost formulată de Matthew Oliver. Acesta consideră că teoria reprezentării nu permite respectarea regulilor aplicabile actualmente în contracte ${ }^{32}$. Cu alte cuvinte, se propune o teorie aplicabilă în cadrul legislaţiei în vigoare şi a teoriilor existente, fără a fi necesară modificarea acestora din urmă. Astfel, algoritmul va fi tratat ca pe o maşinărie, ca pe un instrument al omului, al subiectului de drept, menit să eficientizeze negocierea contractului ori schimbul ofertă/acceptare. Pentru sprijinirea acestei opinii se aduce în prim-plan cauza Quoine Pte Ltd v B2C2 Ltd adusă în faţa Curţii de Apel din Singapore pe data de 24 februarie 2020. Aceasta descrie problema validităţii comerţului şi investiţiilor realizate cu ajutorul Bitcoin şi Etherum. Astfel, Quoine a creat un program prin care a instituit o piaţă de tranzacţionare a Bitcoin şi Etherum. Un algoritm era folosit pentru a negocia şi a încheia contractele avute în vedere. Ca urmare a unei probleme tehnice, algoritmul nu a mai putut accesa datele referitoare la preţurile curente. Partea adeversă, denumită în continuare B2C2, dorind să cumpere Bitcoin, a utilizat preţul său de rezervă, stabilit pentru

30 "(6) "Electronic agent" means a computer program or an electronic or other automated means used independently to initiate an action or respond to electronic records or performances in whole or in part, without review or action by an individual. (7) "Electronic record" means a record created, generated, sent, communicated, received, or stored by electronic means. (8) "Electronic signature" means an electronic sound, symbol, or process attached to or logically associated with a record and executed or adopted by a person with the intent to sign the record.", [Online] la https://www.uniformlaws.org/ committees/community-home? CommunityKey=2c04b76c-2b7d-4399-977e-d5876ba7e034, accesat 1.10.2021.

${ }^{31}$ L.H. Scholz, op. cit., pp. 165-167.

${ }^{32} \mathrm{M}$. Oliver, Contracting by artificial intelligence: open offers, unilateral mistakes, and why algorithms are not agents, în ANU Journal of Law and Technology, Vol. 2, 2021, p. 74, [Online] la https://anujolt.org/article/24466-contracting-by-artificial-intelligence-openoffers-unilateral-mistakes-and-why-algorithms-are-not-agents, accesat 10.10.2021. 
cazul în care ar apărea o situaţie neprevăzută, oferind la schimb Etherum. Preţul Bitcoin a scăzut, determinând mai mulţi investitori să vândă Bitcoin la cel mai bun preţ arătat de platformă până la acel moment, preţ care coincidea cu acela de rezervă al B2C2. În acest fel, B2C2 a cumpărat milione de dolari (tranzacţionaţi în Bitcoin) la o rată de 250 de ori mai bună decât rata stabilită pe piaţă. Aceste proceduri nu au putut fi observate imediat, fiind realizate prin intermediul algoritmilor. Ulterior, Quoine a anulat tranzacţiile, considerându-le greşeli. B2C2, însă a acţionat în justiţie Quoine considerând tranzacţiile realizate contracte definitive şi care obligă părţile ${ }^{33}$.

În baza legii din Singapore, un contract poate fi desfiinţat pentru eroare unilaterală dacă partea care nu se afla în eroare avea cunoştinţă despre această eroare $^{34}$. Quoine s-a folosit de acestea şi, calificând algoritmul drept reprezentant al său, a susţinut în continuare anularea contractelor încheiate sub imperiul unei greşeli sau erori. În plus, algoritmul care a cumpărat pentru $\mathrm{B} 2 \mathrm{C} 2$ avea toate cunoştințele necesare pentru a remarca inclusiv greşeala comisă pe piaţa virtuală. În acest fel, Quoine a arătat că actele juridice au fost încheiate între vânzători şi cumpărători, prin reprezentare. Cu toate acestea, Curtea a stabilit că algoritmul este un instrument, fără raţiune, iar cunoştinţele la care legislaţia se referă sunt acelea ale programatorului, programator care nu cunoştea ivirea defecţiunii ${ }^{35}$. Quoine este principalul actor, aflat în mijlocul a numeroase contracte, toate raporturile realizându-se prin intermediul platformei, care funcţiona şi dirija oferta şi acceptarea părţilor. În acest fel se formau numeroase contracte, dar la baza acestora se aflau termenii din ofertă, alături de acceptare (sau contraofertăacceptare). Soluţia pe care a acceptat-o Curtea a fost aceea de a da efect teoriei contractuale, fundamentându-şi argumentele pe schimbul dintre ofertă şi de $\operatorname{acceptare}^{36}$.

${ }^{33}$ L.B.M.R. Hakim, Do Algorithms Dream of Mistaken Contracts? Quoine Pte Ltd v B2C2 Ltd [2020] SGCA(I) 2, [Online] la https://smulexicon.com/2020/05/15/do-algorithms-dreamof-mistaken-contracts-quoine-pte-ltd-v-b2c2-ltd-2020-sgcai-2/, accesat 2.10.2021.

${ }^{34}$ M. Oliver, op. cit., pp. 75-76.

${ }^{35}$ Quoine Pte Ltd v B2C2 Ltd, Court of Appeal of the Republic of Singapore, în Civil Appeal No. 81, 2019.

"Where it is relevant to determine what the intention or knowledge was underlying the mode of operation of a particular machine, it is logical to have regard to the knowledge or intention of the operator or controller of the machine. In the case of the kitchen blender, this will be the person who put the ingredients in and caused it to work. His or her knowledge or intention will be contemporaneous with the operation of the machine. But in the case of robots or trading software in computers this will not be the case. The knowledge or intention cannot be that of the person who turns it on, it must be that of the person who was responsible for causing it to work in the way it did, in other words, the programmer.", [Online] la https://www.sicc.gov.sg/docs/default-source/modulesdocument/judgments/quoine-pte-ltd-v-b2c2-ltd.pdf-, accesat 20.10.2021.

${ }^{36}$ M. Oliver, op. cit., pp. 74-76. 
În concluzie, la momentul în care încercăm să explicăm modul în care s-ar putea constitui şi stabili un consimţământ valabil în spatele tranzacţiilor realizate, trebuie să includem în algoritm reguli specifice şi nu generale, astfel încât să se poată realiza o ofertă veridică care, odată transmisă, va reda voinţa părţii faţă de care actul final va produce efecte. În cadrul teoriei reprezentării, odată încheiat contractul de către reprezentant, acesta va produce efecte faţă de partea reprezentată fără a fi necesar ca aceasta să îşi fi exprimat consimțământul. S-au acordat doar câteva instrucţiuni algoritmului de către una dintre părți3 ${ }^{37}$. Oferta şi acceptarea sunt schimbate între algoritm (ofertant) şi acceptant. În acest caz, intenţia de a contracta a algoritmului nu va putea fi explicată decât ca pe un posibil transfer de intenţie dinspre ofertant spre algoritm (transfer indirect).

A doua opinie, favorabilă teoriei contractuale, se foloseşte de mecanismul ofertă-acceptare pentru a explica problema consimţământului. Oferta este creată de partea implicată, care o va introduce în algoritm. Acesta va transmite oferta celuilalt posibil contractant realizând un transfer direct de voinţă de a contracta.

Odată îndeplinite aceste condiţii de formare ale contractului, fie pe cale de negociere, fie prin mecanismul ofertă-acceptare, inclusiv consimţământul părţilor, se poate vorbi despre un contract format în mod legal, obligatoriu pentru părţile sale.

Însumând cele anterior menţionate, observăm că nu este exclus ca, în anumite situaţii, algoritmul să poată fi perceput ca pe un reprezentat, iar programatorul, utilizatorul, fabricantul să fie consideraţi reprezentanţi ai acestuia. $\mathrm{Cu}$ toate acestea, la momentul în care se va alege teoria reprezentării drept teorie dominantă va trebui a fi avută în vedere reprezentarea legală. Bineînţeles că s-au formulat critici la adresa acestei opinii, respectiv, faptul că omul va putea deveni reprezentant, în vreme ce algoritmul nu va putea să primească o atare denominaţiune fără a avea personalitate juridică ${ }^{38}$. Astfel, de lege ferenda, s-ar impune o modificare a legii în sensul permiterii utilizării reprezentării drept instrument juridic capabil să explice rolul algoritmului în cadrul procesului de încheiere a contractului.

\section{Moduri de căutare a secvenţelor de text în interiorul contractelor}

În cele ce urmează vor fi prezentate variate modalităţi prin care algoritmul să fie utilizat în sfera contractuală fie pentru a ajuta părţile în crearea consimţământului, fie pentru a eficientiza procesul de încheiere a contractului sub aspectul variabilei temporale. Astfel, pentru a înţelege procesul prin care un algoritm poate găsi o secvenţă de caractere într-un text, trebuie mai întâi să înţelegem un proces mai simplu, prin care un algoritm poate să găsească un număr întreg în interiorul unui şir de numere întregi. Varianta cea mai simplă este de a

37 Ibidem.

${ }^{38}$ V. Ooi, Contracts formed by software: An approach from the law of mistake, în Centre for AI \& Data Governance, 2019, p. 9, [Online] la https://ink.library.smu.edu.sg/ caidg/3, accesat 11.10.2021. 
parcurge şirul, element cu element şi de a ne opri odată ce numarul căutat este găsit. $\mathrm{Cu}$ toate acestea, timpul de căutare creşte în raport cu mărimea şirului de elemente. Spre exemplu, pentru a parcurge $10^{\wedge} 9$ elemente, adică un miliard de elemente ale şirului, un calculator modern are nevoie de 15 secunde. Pentru a parcurge $10^{\wedge} 12$ elemente, calculatorului îi trebuie 4 ore şi 10 minute, iar pentru a parcuge $10^{\wedge} 18$ elemente, calculatorul are nevoie de $475 \mathrm{de}^{\mathrm{ani}}{ }^{39}$. Acum să ne întrebăm câte caractere apar într-un contract. Este fiabil să folosim acest algoritm de căutare pentru a găsi o secvenţă de litere dintr-un contract în timp util?

În acest sens, a devenit utilizat algoritmul căutarii binare. Pentru a înţelege căutarea binară, pornim, de asemenea, de la un exemplu. Astfel, să presupunem că folosim şirul numerelor naturale cuprinse între 1 şi 1024. Numărul pe care îl căutam este 1024. Dacă trasăm mijlocul acestui şir, adică 512, ne punem întrebarea dacă numărul căutat este mai mare sau mai mic decât mijlocul. 1024 este mai mare decât 512, deci vom căuta doar în a doua jumătate a şirului iniţial. Următorul pas este acela de a găsi noul mijloc al şirului de numere aflate între 512 si 1024, adică 768 . Repetăm pasul anterior şi observăm faptul că 1024 este mai mare decât 768, deci restrângem căutarea la a doua jumătate a şirului. Vom repeta aceşti paşi până când ajungem la numărul 1024. Astfel, până la pasul final, vor fi parcurşi doar 10 paşi, comparativ cu 1023 de paşi care ar fi fost parcurşi în cazul abordării primului $\operatorname{algoritm}^{40}$.

În situaţia prezentată ne folosim de exemplul unui şir crescător de numere întregi. $\mathrm{Cu}$ toate acestea, pentru a putea funcţiona algoritmul căutării binare va fi necesar un şir de numere sau caractere ordonat. Astfel, în cazul unui contract, cum ar putea algoritmul să identifice prezenţa unor cuvinte cheie sau a unor secvenţe de text predefinite? Una dintre soluţiile acestei probleme este împărţirea contractului în unităţi mai mici. Presupunând că pornim de la un singur paragraf al contractului, acesta în interiorul algoritmului, poate fi sortat într-o ordine alfabetică, pentru a putea fi căutat cuvântul dorit în interiorul secvenţei de cuvinte. Această sortare se poate face în mai multe modalităţi. Cea mai uşoară rezolvare constă în compararea cuvintelor două câte două şi interschimbarea acestora în cazul în care nu se aflau deja în ordine alfabetică. Această metodă de sortare se realizează prin interclasare. $\mathrm{Cu}$ ajutorul acestei metode, putem ordona atât cuvinte, cât şi propoziţii, pentru a putea folosi ulterior algoritmul căutării binare.

${ }^{39}$ G.L. McDowell, Cracking the Coding Interview 6th Edition, Editura CareerCup, Palo Alto, 2019, pp. 38-39.

${ }^{40}$ Idem, p. 149. 
Search for 9
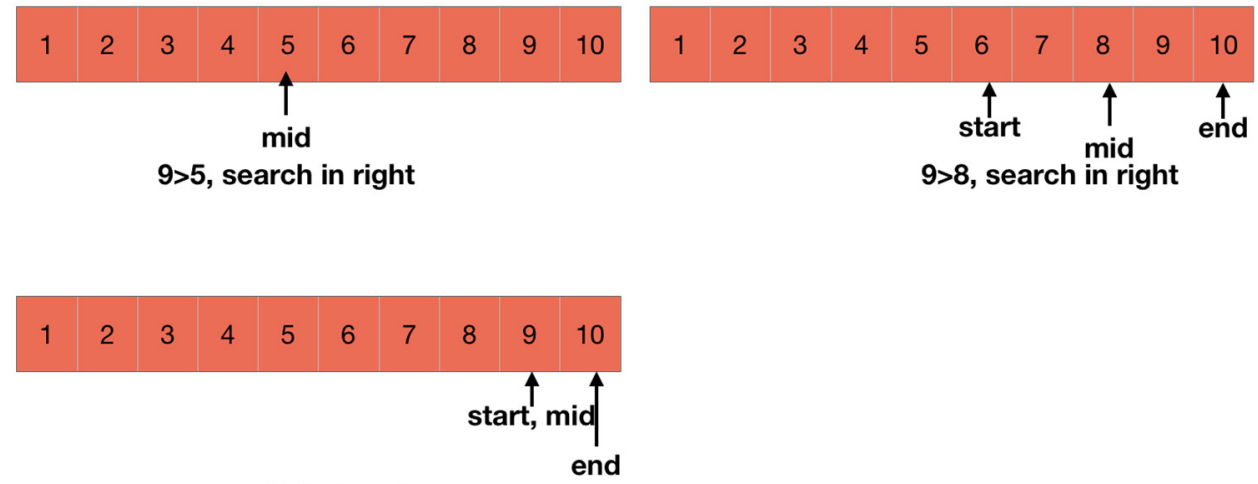

$9=9$, found

Fig. 1. Căutarea binară ${ }^{41}$

Un alt mod de utilizare a algoritmului în sfera contractuală se referă la recunoaşterea semnăturilor. Astfel, pentru a putea recunoaşte o semnătură, un algoritm trebuie ca, în prealabil, să primească drept date de intrare respectiva semnătură în format electronic, spre exemplu un fişier „.png” ce conţine un model al semnăturii. Astfel, printr-un algoritm de recunoaştere a imaginii, pot fi detectate toate semnăturile unui individ din interiorul unui contract.

Recunoaşterea unui obiect dintr-o fotografie sau dintr-o filmare se poate realiza cu niveluri mai mari sau mai mici de acurateţe, în funcţie de tipul de informaţie pe care algoritmul doreşte să îl extragă. Există două funcţii pe care recunoaşterea imaginilor le poate îndeplini, acestea fiind: clasificarea şi segmentarea.

Clasificarea se referă la identificarea unei „clase”, adică a unei categorii în care poate fi încadrată o imagine. Fiecare imagine poate avea o singură clasă ${ }^{42}$.

Segmentarea se referă la localizarea unui element dintr-o imagine în funcţie de pixelii identificaţi. Astfel, pentru unele cazuri, într-un algoritm de recunoaştere a imaginilor, se pune accent pe principiul segmentării. Unul dintre aceste cazuri este identificarea semnăturilor pe un contract, întrucât chiar şi o mică diferenţă faţă de original, ar putea semnala o semnătură falsă. Folosindu-se de nuanţa pixelilor din interiorul unei imagini, algoritmul poate localiza cu exactitate o semnătură pe pagina unui contract.

41 [Online] la https://www.codesdope.com/course/algorithms-binary-search/, accesat 16.10.2021.

${ }^{42} \mathrm{~V}$. Mititelu, Recunoașterea imaginilor în baza indicilor de moment, p. 3, [Online] la https://ibn.idsi.md/sites/default/files/imag_file/469-472_1.pdf, accesat 15.10.2021. 


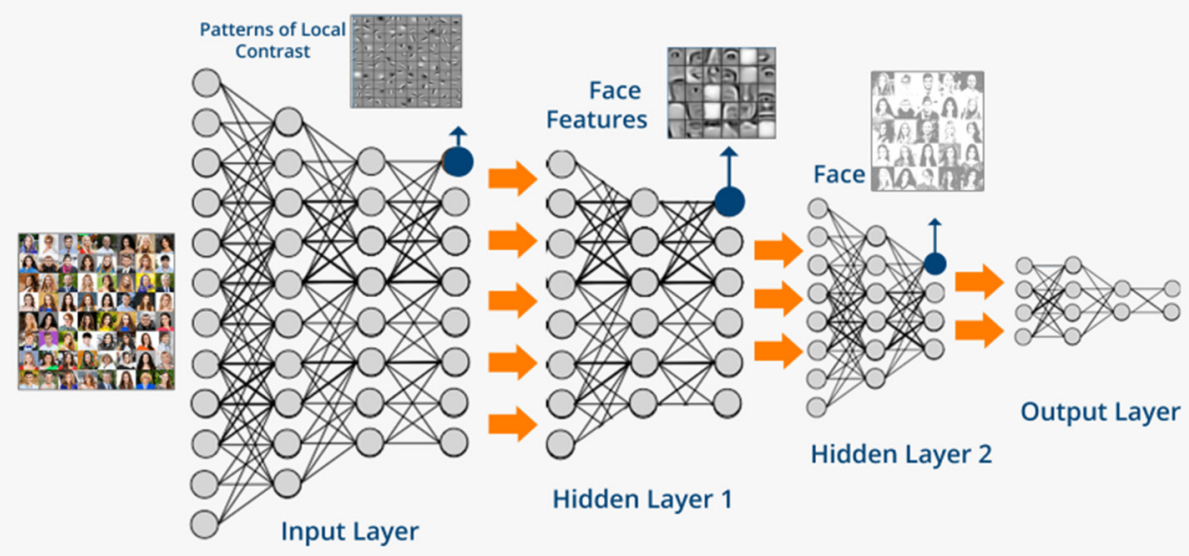

Fig. 2. Reţea neuronală ${ }^{43}$

Recunoaşterea imaginilor are la bază conceptul de „Deep Learning”, care se referă la un set de tehnici de învăţare automate. Acestea funcţionează cu ajutorul unor reţele neuronale artificiale. O reţea neuronală aritificială funcţionează similar cu creierul unui om. Aceasta este formată din mai multe straturi, complexitatea depinzând de tipul de informaţie pe care algoritmul trebuie sa o extragă. În esenţă, o reţea neuronală artificială este doar o funcţie matematică ce necesită date de intrare şi parametri pentru a putea oferi datele de ieşire. Datele de ieşire, în cazul nostru, constau atât în informaţii cu privire la validitatea semnăturilor unui individ din cadrul unui contract, cât şi în numărul de semnături ale respectivei persoane. Astfel, se poate observa cu uşurinţă dacă semnăturile sunt originale sau dacă toate clauzele contractului au fost semnate.

În practică, pentru a utiliza acest algoritm în identificarea semnăturilor unei persoane într-un contract, reţeaua neuronală artificială trebuie sa treacă printr-un proces de învăţare. Un set de imagini trebuie să fie colectate şi introduse ca date de intrare. Odată ce acest set de date a fost creat este esenţial ca, pentru fiecare imagine, programatorul să îi spună algoritmului dacă în ea se află sau nu obiectul căutat, împreună cu locaţia sa. După ce tot setul de date de intrare a trecut deja prin acest proces, urmează ca algoritmul să înceapă învăţarea. Reţeaua neuronală trebuie să înveţe un concept prin trecerea peste un număr mare de exemple.

Scopul final al acestui întreg proces este acela de a crea un algoritm care poate spune cu exactitate dacă semnătura unui individ din cadrul unui contract a fost falsificată sau este originală.

Utilitatea unui astfel de algoritm poate fi extinsă şi la aflarea numărului de semnături din cadrul unui contract, cu scopul de a trece peste citirea contractului

43 [Online] la https://www.researchgate.net/figure/Structure-of-a-deep-neural-netDNN-for-facial-recognition-6_fig2_325530258, accesat 16.10.2021. 
mai eficient. Astfel, îmbinând algoritmul căutarii binare cu o reţea neuronală artificială care detectează prezenţa semnăturilor unui individ, se poate realiza citirea corectă a unui contract într-un timp foarte scurt.

Algoritmul va putea, de asemenea, să fie perceput drept fundament al contractelor inteligente. Acestea sunt programe pentru calculator, respectiv, protocoale de tranzacţie destinate să execute, să controleze sau să documenteze automat evenimentele şi acţiunile relevante din punct de vedere juridic în conformitate cu termenii unui contract sau ai unui acord. Obiectivele contractelor inteligente sunt reducerea nevoii de intermediari de încredere şi a costurilor de executare, precum şi reducerea oricăror altor costuri ${ }^{44}$.

Din perspectiva programatorului, un astfel de contract va purta denumirea de „smart contract” dacă, odată ce a fost transferat în format electronic, acestuia i se poate aplica un algoritm care să eficientizeze procesul de încheiere a respectivului act. Spre exemplu, acesta poate parcurge în întregime şi identifica toate clauzele contractului într-o perioadă de timp semnificativ mai scurtă decât un om sau poate identifica tentativele de falsificare a semnăturilor cu o precizie mult mai mare decât un om.

Printre primele tehnologii care aplică un algoritm ce poate fi asemănat cu un algoritm dintr-un „smart contract” se află tonomatele de cafea. Algoritmul din spatele unui simplu tonomat de cafea este foarte uşor de implementat întrucât aparatul, în orice moment, se poate afla doar în una dintre cele patru situaţii:

1. Tonomatul are suficient credit introdus în el şi are suficientă cafea, ceea ce rezultă în dispensarea cafelei şi încheierea contractului.

2. Tonomatul are suficient credit introdus în el, dar nu are suficientă cafea, caz în care nu se poate încheia contractul dintre algoritm şi cumpărător.

3. Tonomatul nu are suficient credit introdus în el şi are suficientă cafea, moment în care algoritmul cere sa fie indroduşi mai mulţi bani.

4. Tonomatul nu are suficient credit indrodus în el şi nu are suficientă cafea, ceea ce duce din nou la imposibilitatea încheierii unui contract între algoritm şi om.

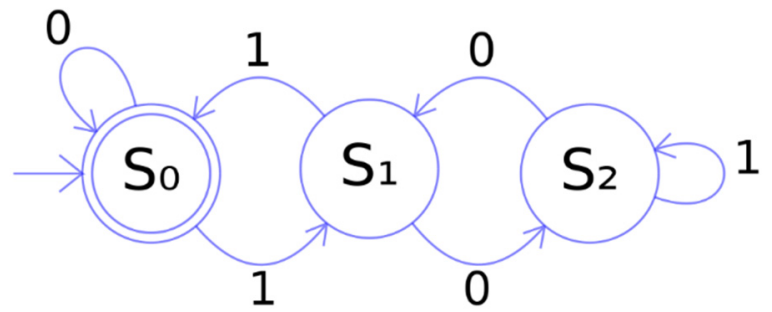

Fig. 3. Finite state automata ${ }^{45}$

\footnotetext{
${ }^{44}$ R. Herian, Smart contracts: a remedial analysis, în Information \& Communications Technology Law, 2020, lucrare utilizată integral, [Online] la https://www.tandfonline.com/doi/abs/10.1080/13600834.2020.1807134, accesat 17.10.2021.

45 [Online] la https://dndimitri.eu/2020/02/09/deterministic-finite-state-automota-forregular-expres, accesat 16.10.2021.
} 
Astfel, pe baza unui algoritm ce trece doar prin patru cazuri simple, se poate crea un contract între un om şi o maşinărie. Cu toate acestea, ce se întâmplă în cazul în care cineva a depus suficient credit în tonomat, dar nu mai există cafea pentru a fi dispensată? Algoritmul nu prevede o soluţie pentru un asemenea caz. $\mathrm{Cu}$ toate acestea, algoritmul care este folosit la un contract smart este cu mult mai avansat decât cel folosit la un simplu tonomat de cafea. Pentru a putea controla şi identifica toate posibilele situaţii care pot interveni în procesul de încheiere al unui contract, un algoritm ar produce un număr foarte mare de posibile scenarii care să aibă loc.

\section{Concluzii}

Având în vedere cele expuse putem conchide faptul că algoritmul poate avea statutul de participant în procesul de încheiere a contractului, dar răspunsul nu este unul absolut, ci nuanţat în funcţie de opţiunea părţilor. Acestea îl pot privi drept un reprezentant al voinţei lor şi care va crea o ofertă în raport cu termenii şi limitările generale impuse de subiectul reprezentat. $\mathrm{O}$ a doua soluţie pentru care pot opta părţile este aceea de a respecta cadrul legal şi de a folosi mecanismul ofertei-acceptării în vederea aducerii în prim-plan a consimţământului real al viitorilor contractanţi. Cu alte cuvinte, îmbinând regula de drept cu interesul părţii, se creează o soluţie care să explice, de fapt, ceea ce doresc părţile a realiza prin intermediul contractului.

\section{Referinţe}

Bob M.D., Manual elementar de drept privat roman, Editura Universul Juridic, Bucureşti, 2019

Chopra S., White L.F., Artificial Agents and the Contracting Problem: A Solution Via an Agency Analysis, în University of Illinois fournal of Law Technology \& Policy, 2010

Gaius, Instituţiunile, trad. Aurel N. Popescu, Editura Academiei Republicii Socialiste România, Bucureşti, 1982

Gellers J.C., Rights for Robots. Artificial Intelligence, Animal and Environmental Law, Editura Routledge, New York, 2021

Herian R., Smart contracts: a remedial analysis, în Information \& Communications Technology Law, 2020, https://doi.org/10.1080/13600834.2020.1807134

Hogg M., Promises and Contract Law. Comparative Perspectives, Editura Cambridge University Press, The Edinburgh Building, Cambridge, 2011

McDowell G.L., Cracking the Coding Interview 6th Edition, Editura CareerCup, Palo Alto, 2019

Oliver M., Contracting by artificial intelligence: open offers, unilateral mistakes, and why algorithms are not agents, în ANU Journal of Law and Technology, Vol. 2, 2021

Ooi V., Contracts formed by software: An approach from the law of mistake, în Centre for AI \& Data Governance, 2019, http://dx.doi.org/10.2139/ssrn.3322308

Pagallo U., The Laws of Robots: Crimes, Contracts, Torts, Editura Springer Science+Business Media Dordrecht, Dordrecht Heidelberg New York London, 2013

Pop L., Popa I.F., Vidu S.I., Curs de drept civil. Obligaţiile, Editura Universul Juridic, Bucureşti, 2015

Quinot G., Offer, Acceptance, and the Moment of Contract Formation, in loc. cit., Hector MacQueen, Reinhard Zimmermann, European Contract Law. Scots and South African Perspectives, Editura Edinburgh University Press, Edinburgh, 2006 
Reier Forradellas R.F., Digital Transformation and Artificial Intelligence Applied to Business: Legal Regulations, Economic Impact and Perspective, în Laws, 2021, https://doi.org/10.3390/laws10030070

Scholz L.H., Algorithmic Contracts, în Stan. Tech. L. Rev., nr. 128, Stanford, California, 2017

Supiot A., Homo juridicus: eseu despre funcţia antropologică a dreptului, Editura Rosetti Educational, Bucureşti, 2011

Ungureanu C.T., Drept civil. Partea generală. Persoanele, Editura Hamangiu, Bucureşti, 2013

Van Beers B., The Changing Nature of Law's Natural Person: The Impact of Emerging

Technologies on the Legal Concept of the Person, German Law Journal, Vol. 18, No. 03, https://doi.org/10.1017/S2071832200022069 